\title{
Influence of superabsorbent polymer on the splitting tensile strength and fracture energy of high-performance concrete
}

\author{
Babatunde James Olawuyi ${ }^{1,2 *}$ and William Peter Boshoff ${ }^{1}$ \\ ${ }^{1}$ Unit for Construction Materials, Department of Civil Engineering, Stellenbosch University, Private Bag X1, Matieland 7602, \\ Stellenbosch, South Africa \\ ${ }^{2}$ Department of Building, School of Environmental Technology, Federal University of Technology, P.M.B 65, Minna, Nigeria
}

\begin{abstract}
Superabsorbent polymers (SAP) addition as an internal curing (IC) agent in concrete is an approach being adopted for the mitigation of autogenous shrinkage. Micro-voids created by SAP are arguably believed to be detrimental to the mechanical properties especially the fracture tendencies of the concrete. This paper presents the report of an experimental study of SAP's influence on the splitting tensile strength and fracture energy of low water/binder (W/B) high-performance concrete (HPC). Reference HPC mixtures $\left(\mathrm{M}_{1 \mathrm{~F}}, \mathrm{M}_{1 \mathrm{~s}}, \mathrm{M}_{2}\right.$ and $\left.\mathrm{M}_{3}\right)$ designed for a 28-day minimum cube compressive strength of $70 \mathrm{~N} / \mathrm{mm}^{2}(\mathrm{MPa})$ were examined for the effect of SAP grain size, content and binder type on the above stated properties. Wedge splitting test was carried out on $100 \mathrm{~mm}$ cube specimen of HPC containing varied SAP contents $\left(0.2,0.3\right.$ and 0.4 by weight of binder $\left(b_{w o b}\right)$ and SAP sizes, cured by water immersion for 28,56 and 90 days respectively. The results obtained was plotted as splitting force $\left(\mathrm{F}_{\mathrm{sp}}\right.$ in $\mathrm{kN}$ ) against the crack mouth opening displacement (CMOD in $\mathrm{mm}$ ) for computing the work of fracture $\left(\mathrm{W}_{\mathrm{f}}\right)$, which is the area under the $\mathrm{F}_{\mathrm{sp}}-\mathrm{CMOD}$ curve. The study concludes that the splitting tensile strength and fracture energy of the HPCs are not directly affected by SAP addition (i.e. neither grain size nor content).
\end{abstract}

\section{Introduction}

High performance concrete (HPC) is defined by ACI (1999) as concrete meeting special combinations of performance and uniformity requirements that cannot always be achieved routinely using conventional constituents and normal mixing, placing, and curing practice ([1]. It is a type of concrete specially designed to meet a combination of performance and requirements which specifically includes high strength or high early strength, durability and high elastic modulus [2, 3]. Its application includes precast pylons, piers and girders of many long span bridges in the world; tunnels, tall and ultra-high buildings; shotcrete repairs, poles, parking garages and agricultural applications [2]. The production involves high contents of fines (i.e. cement and other pozzolanic materials) and admixtures requiring good proportioning and handling towards achieving good workability, curing needs and other specific performance requirements. This type of concrete is however known to be susceptible to autogenous-shrinkage-caused-cracking which superabsorbent polymers (SAP) incorporation as an internal curing (IC) agent in HPC is reported as an effective approach to mitigate. SAP's created microvoids however are arguably believed to be detrimental to the mechanical properties especially the fracture tendencies of the concrete.
The fracture energy $G_{F}(N / m)$, defined as energy required for propagating a tensile crack of unit area is recommended to be determined from related tests with axial tensile strength adjudged most appropriate [4]. The factors influencing fracture energy $\left(\mathrm{G}_{\mathrm{F}}\right.$ - values $)$ of normal strength concrete as highlighted in literature are water/cement $(\mathrm{W} / \mathrm{C})$ ratio; maximum aggregate size, age of concrete, curing condition, and size of structural members $[5,6,7]$. The same factors' influence on fracture energy applies to HPC but at a smaller magnitude. Hansen, et al., [8] argue that aggregate type and content seem to have the greatest influence on fracture energy of HPC as a phenomenon caused by transition from interfacial fracture to trans-aggregate fracture.

ICCRRR 2018 with focus on the increasingly important aspect in modern infrastructure provision and retention (i.e. appropriate repairs, maintenance, rehabilitation, and if necessary retrofitting) of existing infrastructure with a view to extending its life and maximizing its economic return, hereby presents an opportunity for disseminating outcomes of recent study on SAP incorporation in HPC and the influence on its fracture properties. This paper hereby reports on the experimental study of the influence of varied SAP grain sizes and contents on the splitting tensile strength and fracture energy of HPC of varied binder combination types, water/binder (W/B) and curing age. The modified

*Corresponding author: babatunde@futminna.edu.ng 
wedge splitting test setup - an approach for obtaining nonlinear fracture mechanics parameters based on [9] was adopted with two wedges pressed symmetrically between four roller bearings in order to split the specimen into two halves.

\section{Experimental procedure}

\subsection{Materials}

The materials used for the study are SAP, natural sand, crushed greywacke stone, cement (CEM I $52.5 \mathrm{~N}$ ), silica fume (SF), Fly Ash (FA), Corex Slag (CS), water and superplasticiser. Two grain sizes of SAP $\left(\mathrm{SP}_{1}\right.$ and $\mathrm{SP}_{2}$ as described in earlier publication [10] at varied SAP contents $(0 \%, 0.2 \%, 0.3 \%$ and $0.4 \%)$ by weight of binder $\left(b_{\text {wob }}\right)$ were used for the study. The SAP is a thermoset polymer, specifically covalently cross-linked polymer of acrylic acid and acrylamide, obtained from bulk solution polymerisation and neutralised by alkali hydroxide, which according to Schrofl et al., [11] have been proven efficient as internal curing agent in concrete. The absorption capacity determined by tea-bag test as reported in [12] is $250 \mathrm{~g} / \mathrm{g}$ in distilled water and $25 \mathrm{~g} / \mathrm{g}$ in cement pore solution (CPS) for both the $\mathrm{SP}_{1}$ and $\mathrm{SP}_{2}$. The SAP particles were stored (with exposure to moisture prevented) in as received sealed plastic bag inside a wooden cupboard until use.

CEM I 52.5 N supplied by PPC, South Africa conforming to $[13,14]$ served as the main binder. SF, by SiliconSmelters of the FerroAltantica group; FA from AshResources and CS supplied by PPC; all in powdered form were used as SCM for the various HPC mixtures as required by the mix design. The blends of the binders were categorised into three binder types (1,2 and 3): Binder types 1 - a combination of CEM I $52.5 \mathrm{~N}$ and SF $\left(7.5 \% b_{w o b}\right)$, also referred to as binary cement and adopted for reference HPC mixtures $\mathrm{M}_{2}(0.25 \mathrm{~W} / \mathrm{B})$ and $\mathrm{M}_{3}(0.30 \mathrm{~W} / \mathrm{B})$; Binder Type 2 - which composed of CEM I $52.5 \mathrm{~N}$, SF $\left(7.5 \% \mathrm{~b}_{\text {wob }}\right)$ and FA $\left(17.5 \% \mathrm{~b}_{\text {wob }}\right)$ used for $\mathrm{M}_{1 \mathrm{~F}}(0.2 \mathrm{~W} / \mathrm{B})$; and Binder Type 3 - made of CEM I $52.5 \mathrm{~N}, \mathrm{SF}\left(7.5 \% \mathrm{~b}_{\mathrm{wob}}\right)$ and CS $\left(17.5 \% \mathrm{~b}_{\mathrm{wob}}\right)$ used for $\mathrm{M}_{1 \mathrm{~S}}(0.2 \mathrm{~W} / \mathrm{B})$. Binder Types 2 and 3 are referred to as ternary cements. The details of the mix constituents for the reference HPC mixtures made with the respective binder types is presented [10].

The Natural sand used had minimum particle size of $300 \mu \mathrm{m}$ (i.e. all the particles smaller than $300 \mu \mathrm{m}$ removed using the sieving method) in compliance with requirement for fine aggregate specification for HPC production [3, 15, 16]. The sand has the following physical characteristics: Fineness Modulus $-\mathrm{FM}=2.79$, Coefficient of uniformity $-\mathrm{C}_{\mathrm{u}}=2.43$, Coefficient of curvature $-\mathrm{C}_{\mathrm{c}}=1.02$ and dust content $=0.3 \%$. This conforms to medium sand classification according to
[17]. $13 \mathrm{~mm}$ crushed greywacke stone served as coarse aggregate in compliance with typical HPC mixes found in literature $[3,16,18]$. The crushed stone was washed and spread in the open air for surface drying before measuring the required quantity for particular reference HPC mixture production. This was to reduce the dust content of the coarse aggregate in order to achieve low water demand for the HPC mixtures, especially the $\mathrm{M}_{1 \mathrm{~F}}$ and $\mathrm{M}_{1 \mathrm{~s}}$ with extremely low $\mathrm{W} / \mathrm{B}$.

\subsection{Methods}

Splitting tensile strength and fracture energy for the HPC mixtures were determined through the modified wedge splitting test approach based on the works of [ 9,19$]$. The specimen for the wedge splitting test was cast with a $30 \mathrm{~mm} \times 20 \mathrm{~mm}$ groove introduced by insertion of a wooden block and cured in the water-bath. It was further notched to $50 \mathrm{~mm}$ depth from the cube specimen bottom (Figure 1 (b)) at the required curing ages $(28,56$ and 90 days) and an epoxy glue was used to attach PVC clips (Figure 1 (a)) fabricated to hold LVDTs at the groove edge for a measurement of the CMOD during the test. The test setup developed as shown in Figure 1 (c) using a loading assembly $\left(14^{\circ}\right.$ wedge plate welded to IPE 160 I-section $\left(160 \times 82 \times 15.8 \mathrm{~kg} / \mathrm{m}^{3}\right.$ I-section $)$ ) made to move within two $\varnothing 25 \mathrm{~mm}$ needle roller bearings (NKI 25/30) attached to the sides of fabricated steel frame (made of C-channels) for a transfer of the vertically applied load to horizontal loading on the cube specimen.

The cube was placed on a base plate with two $10 \mathrm{~mm}$ diameter bars welded to it (for stability) as observed in $[20,21]$ to induce crack opening from the notched groove-end of the wedge splitting specimen instead of the single bar centrally placed specified in $[9,19]$

This is to ensure stability of the cube specimen during testing. An interlayer of $4 \mathrm{~mm}$ thick hardboard of $8 \mathrm{~mm}$ width was placed on the $10 \mathrm{~mm}$ diameter bars on the base plate (as shown in Figure 1 (d)) to prevent direct transfer of axial force from the base when carrying out the wedge splitting test.

The load was applied at a crack mouth opening rate of $0.1 \mathrm{~mm} / \mathrm{min}$ in a closed loop servo control machine (Instron $50 \mathrm{kN}$ actuator by Instron Ltd.) having maximum loading capacity of $50 \mathrm{kN}$ (dynamic) / 62.5 $\mathrm{kN}$ (static). The crack opening displacement (COD) was measured on the specimen with two LVDTs attached using the plastic holders (Figure 1 (a)) connected directly to the Instron machine ensuring crack opening control of the test set up and a direct data transfer to a dedicated computer. A total of $288(100 \mathrm{~mm})$ cube HPC samples were studied for splitting tensile strength and fracture energy. An average of the three tests per specific sample gave the values reported in this work. 
(a)

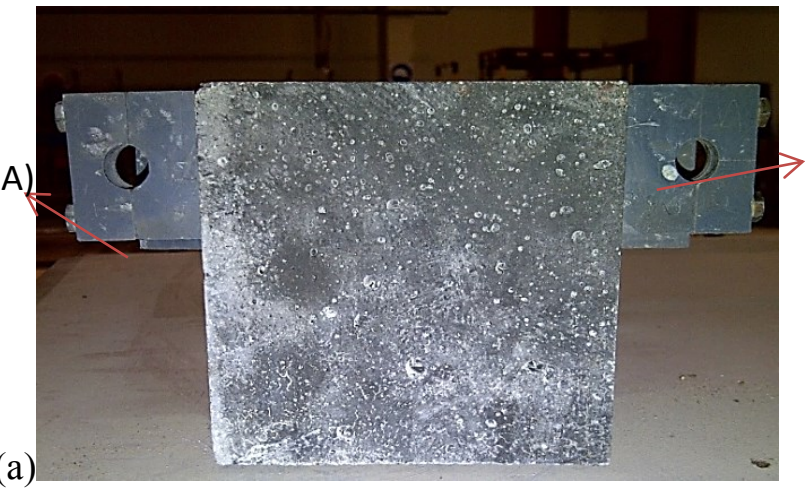

(A)

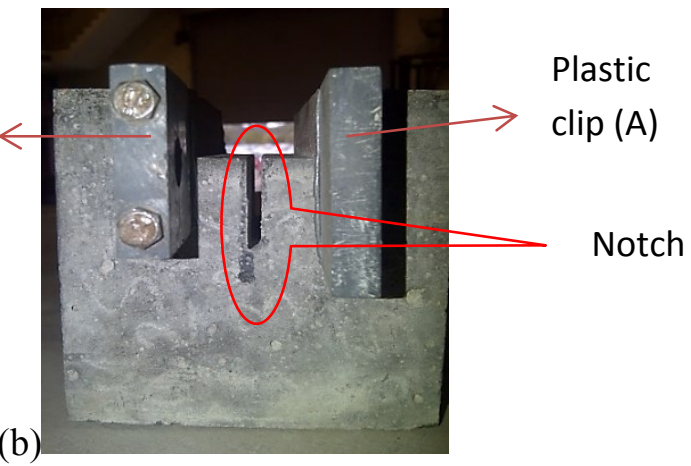

$\rightarrow(B$

(E)

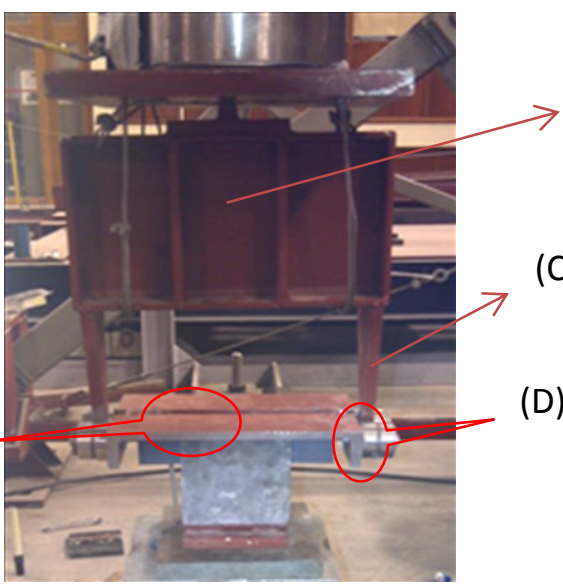

(d)

(D)

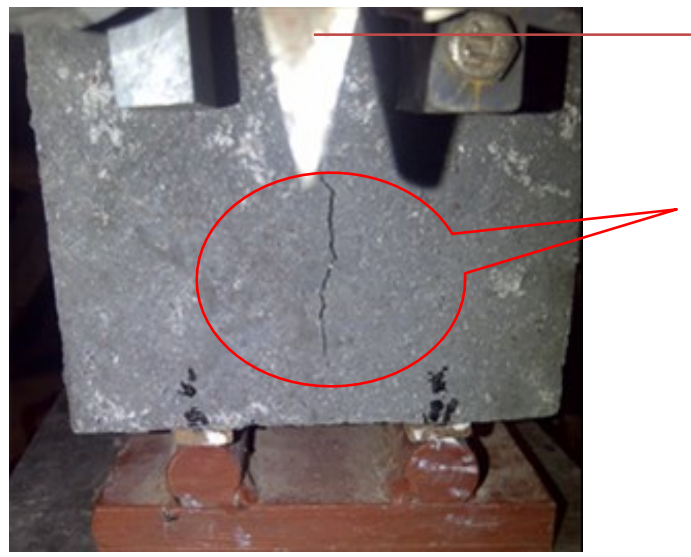

$\rightarrow$ The wedge (C)

Crack

propagation

Fig 1: Test setup for wedge splitting test - (a) shows the plastic clip (LVDT holder) glued to concrete specimen; (b) the groove $(30 \mathrm{~mm} \times 20 \mathrm{~mm})$ and notch $(20 \mathrm{~mm}$ deep); (c) the complete wedge splitting setup and (d) the crack propagation on the cube specimen.

*Note that the label (A) in Figure 3above is plastic clip; (B) is the IPE 160 I-section; (C) is the metal wedge; (D) is the two Ø25 mm needle roller bearings and $(\mathrm{E})$ is the fabricated steel frame (made of C-channels).

\section{Results and discussion}

\subsection{Results}

The results extracted from the test setup as explained earlier was the splitting force $\left(\mathrm{F}_{\mathrm{sp}}\right.$ in $\left.\mathrm{kN}\right)$ against the crack mouth opening displacement (CMOD in $\mathrm{mm}$ ). Figure 1 shows a typical set of results for triplicate specimen (for $\mathrm{M}_{1 \mathrm{~S}} \mathrm{SP}_{1}-0.4$ after 28 days curing).

The data obtained was then computed for each sample for calculation of the work of fracture $\left(\mathrm{W}_{\mathrm{f}}\right)$ which is the area under the $\mathrm{F}_{\mathrm{sp}}$ - CMOD curve using the trapezoidal rule in accordance to $[19,9]$ recommendations and hence the calculation of the fracture energy $\left(\mathrm{G}_{\mathrm{F}}\right)$. Figures 3 to 6 presents the plots of fracture energy against curing age for the respective HPC mixtures while the detailed results for the fracture energy as required by [9] with values of the cube compressive strength $\left(f_{c, \text { cube }}\right)$, E-modulus $\left(\mathrm{E}_{\mathrm{c}}\right)$ and the Splitting force $\left(\mathrm{F}_{\mathrm{sp}}\right)$ provided can be found in [22] Tables $5.12 \& 5.13$.

An assessment of the results reveals no particular trend on influence of SAP addition on the splitting tensile strength and fracture energy of the HPCs. The works of [23] reported similar or higher splitting tensile strength for SAP modified concretes on the 28 days.

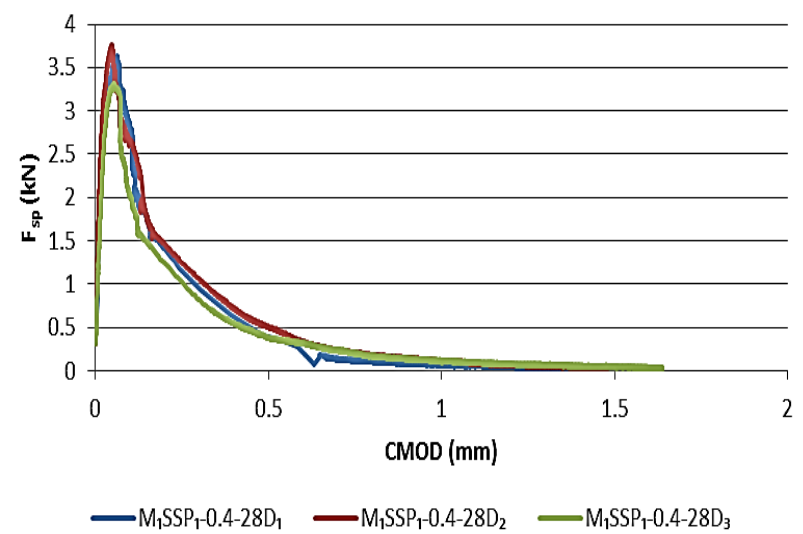

Fig 2: Typical plot of data extracted from Wedge Splitting Test for $W_{f}$ and $G_{f}$ Calculation

The explanation offered for the better splitting tensile strength at 28 days in SAP modified concrete by [24] is that SAP, in parallel to shrinkage mitigation, successfully increased the tensile cracking resistance of the cement-based system. This explanation is applicable in this test too as the reason for no significant reduction in tensile splitting strength of the SAP modified HPC. 


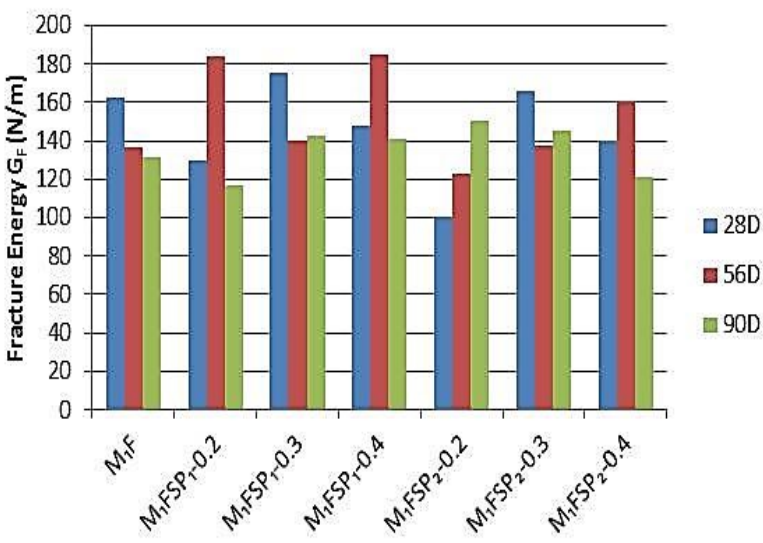

Figure 3: Fracture Energy $\left(G_{F}\right)$ of $M_{1 F}$

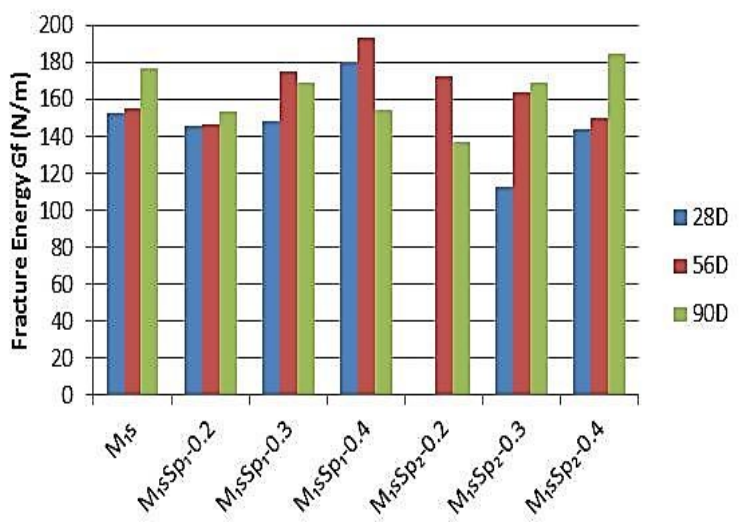

Figure 4: Fracture Energy $\left(G_{F}\right)$ of $M_{1 S}$

The fracture energy values are generally within the same range of $130 \mathrm{~N} / \mathrm{m}$ to $185 \mathrm{~N} / \mathrm{m}$ for all specimens with or without SAP addition except in a few instances which deviates from the range. The $\mathrm{G}_{\mathrm{F}}$ value obtained is within the expected range for concrete of this strength range made from maximum aggregate size of $13 \mathrm{~mm}$ [4]. A check of the $G_{F}$ in line with MC 2010 provision on basis of maximum aggregate size $\left(\mathrm{G}_{\mathrm{F}}=\mathrm{a}\right.$. $\left.\Theta^{\mathrm{n}}\right)$ gave $183.15 \mathrm{~N} / \mathrm{m}$ while a second check using a characteristic compressive strength of $90 \mathrm{~N} / \mathrm{mm}^{2}$ (using $\mathrm{G}_{\mathrm{f}}=72 . \mathrm{f}_{\mathrm{cu}}{ }^{0.18}$ ) gave a value of $161.85 \mathrm{~N} / \mathrm{m}$. Both checks therefore show that $\mathrm{G}_{\mathrm{F}}$ values obtained are similar to the MC 2010 [4] provisions. The result for the 28 day test for $\mathrm{M}_{1 \mathrm{~S}} \mathrm{SP}_{2}-0.2$ sample was however lost as the samples failed suddenly during testing due to poor closed loop control.

Figures 3 to 6 shows that curing age influence on the $\mathrm{G}_{\mathrm{F}}$ values cannot also be placed into any particular trend. The splitting force was also observed to generally maintain a value range of $3.0 \mathrm{kN}$ to $5.0 \mathrm{kN}$ for all the HPCs examined except two cases of inconsistencies. There was however cases of observed reduction in the value of $\mathrm{G}_{\mathrm{f}}$ with decrease in age (Figure $3, \mathrm{M}_{1 \mathrm{~F}}$ and $\left.\mathrm{M}_{1 \mathrm{~F}} \mathrm{SP}_{1}-0.2\right)$

It is observed that three variables $(\mathrm{W} / \mathrm{B}, \mathrm{SAP}$ grain size and SAP content - asterisks' $\left({ }^{* 1}\right)$, Table 1) in that order had significant effect individually on the force of splitting. W/B showing the highest influence is as expected, since higher W/B in concrete should infer lower force required to split the concrete specimen. The two variable interactions further affirm the influence of

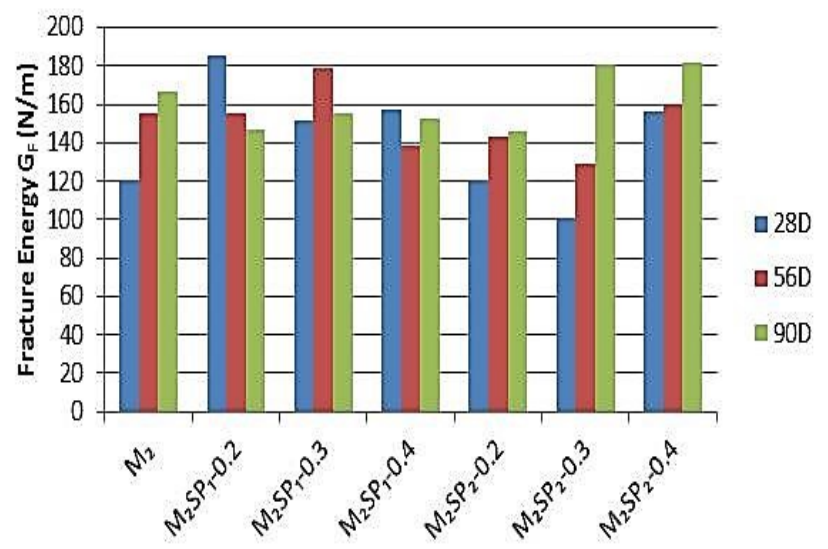

Figure 5: Fracture Energy $\left(G_{F}\right)$ of $M_{2}$

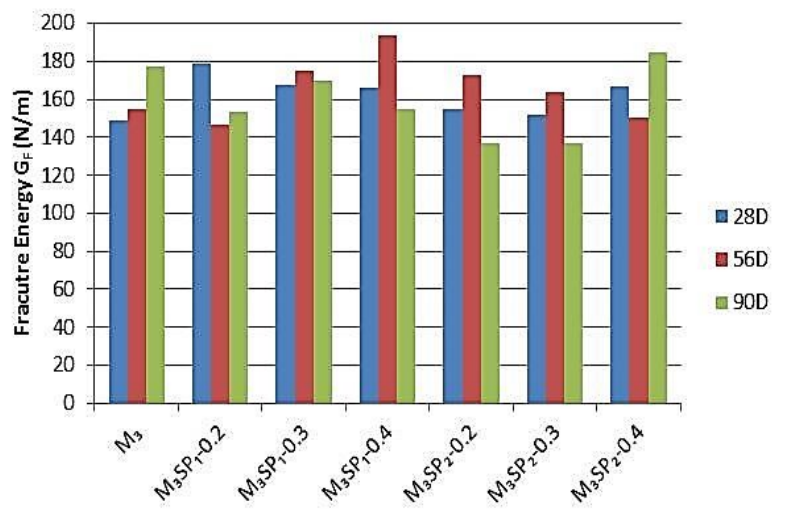

Figure 6: Fracture Energy (GF) of $M_{3}$

SAP content and SAP type when combined with binder type on the splitting force of the HPC containing SAP.

Figure 7 show that the mean splitting force (from the statistical analysis) has a negative correlation with SAP content. The splitting force (and hence the splitting strength) decreases as the SAP content increases. The widest scatter of splitting force value was noted to be in the reference mixtures, an indication of the greater influence of $\mathrm{W} / \mathrm{B}$ on the varied splitting force obtained for reference HPC mixtures. Figure 7 further shows that $\mathrm{SP}_{2}$ inclusion in HPC resulted in lower splitting force than $\mathrm{SP}_{1}$. The splitting force of HPC containing $\mathrm{SP}_{1}$ was similar to that of the reference mixtures.

The results of general linear - univariate analysis (using SPSS 22) of fracture energy of the HPC with SAP as presented in Table 1 reflect that binder type, SAP type and SAP content (asterisks $\left({ }^{* 1}\right)$, in this decreasing order) has significant individual effect on the outcome of fracture energy, while the effect of W/B is not significant as a single factor. At two variable combinations level, SAP type combined with binder type has the least significant effect. Influence of combinations of W/B*curing age, SAP type*curing age and binder type*curing age (asterisks $(* 2)$ ) are noted to be very significant at the two factor analysis level.

Three and four factor analysis however affirmed the postulation that binder type is the more influential factor than the W/B in combination with the three other variables (SAP content, SAP type and curing age). 
Figure 8 shows a plot of the $\mathrm{G}_{\mathrm{F}}$ of the HPC mixtures against SAP contents as influenced also by the binder type. The figure shows that the fracture energy of the HPCs increases slightly with increasing SAP contents. The HPCs with the highest SAP content has the highest mean fracture energy, followed closely by the reference mixtures. This implies that although the splitting force was higher at lower SAP content, the ductility of the HPC increases as the SAP contents increase. The ternary binders (Type 2 and Type 3 ) were generally observed to show better scatter than the binary binders (Type 1).

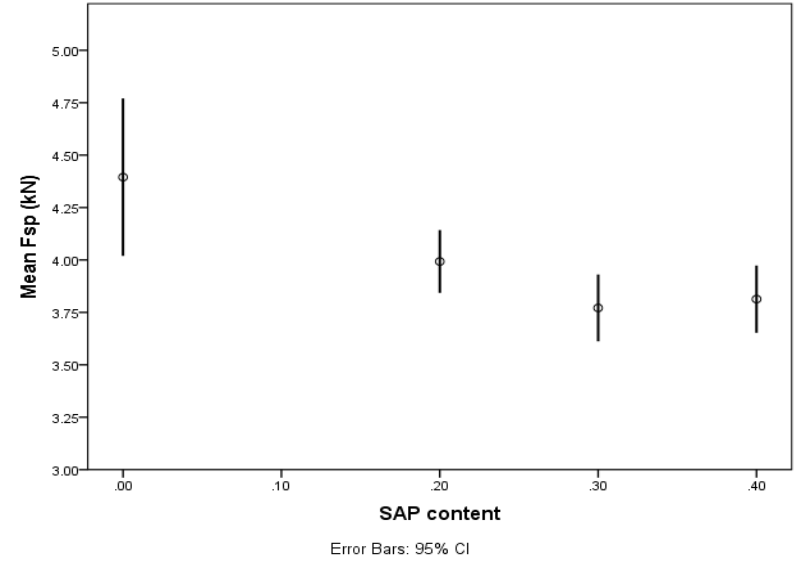

Fig 7: Mean Splitting Force $\left(\mathrm{F}_{\mathrm{sp}}\right)$ vs, SAP content

Table 1: Tests of Between-Subjects Effects for Splitting Force $\left(F_{\mathrm{sp}}\right)$

\begin{tabular}{|c|c|c|c|c|c|}
\hline Source & \begin{tabular}{|l|}
$\begin{array}{l}\text { Type III Sum of } \\
\text { Squares }\end{array}$ \\
\end{tabular} & df & \begin{tabular}{|l|} 
Mean \\
Square \\
\end{tabular} & $\mathrm{F}$ & Sig. \\
\hline Corrected Model & $69.768^{\mathrm{a}}$ & 82 & .851 & 3.401 & .000 \\
\hline Intercept & 2794.699 & 1 & 2794.699 & 11171.046 & .000 \\
\hline \multicolumn{6}{|l|}{ Single factor Analysis } \\
\hline $\mathrm{W} / \mathrm{B}$ & \begin{tabular}{|l|}
11.774 \\
\end{tabular} & 1 & 11.774 & 47.064 & $.000 * 1$ \\
\hline SAP content & 1.642 & 2 & .821 & 3.281 & $.041 * 1$ \\
\hline SAP type & 2.314 & 1 & 2.314 & 9.250 & $.003^{* 1}$ \\
\hline Binder type & .015 & 1 & .015 & .058 & .810 \\
\hline Curing Age & .791 & 2 & .395 & 1.580 & .210 \\
\hline \multicolumn{6}{|l|}{ Two Factor Analysis } \\
\hline $\mathrm{W} / \mathrm{B} * \mathrm{SAP}$ content & .616 & 2 & .308 & 1.230 & .296 \\
\hline W/B * SAP type & .028 & 1 & .028 & .110 & .740 \\
\hline W/B $*$ Curing Age & .018 & 2 & .009 & .036 & .964 \\
\hline SAP content $*$ SAP type & .097 & 2 & .048 & .193 & .824 \\
\hline SAP content $*$ Binder type & 1.929 & 2 & .964 & 3.855 & $.024 * 1$ \\
\hline SAP content $*$ Curing Age & .497 & 4 & .124 & .496 & .739 \\
\hline SAP type * Binder type & 5.658 & 1 & 5.658 & 22.617 & $.000^{* 1}$ \\
\hline SAP type * Curing Age & .621 & 2 & .310 & 1.241 & .293 \\
\hline Binder type * Curing Age & .235 & 2 & .118 & .470 & .626 \\
\hline \multicolumn{6}{|l|}{ Three Factor Analysis } \\
\hline $\mathrm{W} / \mathrm{B} * \mathrm{SAP}$ content $*$ SAP type & .670 & 2 & .335 & 1.339 & .266 \\
\hline W/B $*$ SAP content $*$ Curing Age & .420 & 4 & .105 & .420 & .794 \\
\hline W/B $*$ SAP type $*$ Curing Age & .912 & 2 & .456 & 1.822 & .166 \\
\hline SAP content $*$ SAP type * Binder type & .268 & 2 & .134 & .536 & .586 \\
\hline SAP content $*$ SAP type $*$ Curing Age & 1.621 & 4 & .405 & 1.620 & .174 \\
\hline SAP content $*$ Binder type $*$ Curing Age & 2.024 & 4 & .506 & 2.022 & .095 \\
\hline SAP type * Binder type * Curing Age & .043 & 2 & .021 & .085 & .918 \\
\hline \multicolumn{6}{|l|}{ Four Factor Analysis } \\
\hline W/B * SAP content * SAP type * Curing Age & .966 & 4 & .241 & .965 & .429 \\
\hline SAP content * SAP type * Binder type * Curing Age & 1.307 & 3 & .436 & 1.741 & .162 \\
\hline Error & 30.521 & 122 & .250 & & \\
\hline Total & 3271.795 & 205 & & & \\
\hline Corrected Total & 100.289 & 204 & & & \\
\hline
\end{tabular}

a. R Squared $=.696($ Adjusted R Squared $=.491)$ 
Table 2: Tests of Between-Subjects Effects for Fracture Energy

\begin{tabular}{|c|c|c|c|c|c|}
\hline Source & $\begin{array}{l}\text { Type III Sum of } \\
\text { Squares }\end{array}$ & df & Mean Square & $\mathrm{F}$ & Sig. \\
\hline Corrected Model & $86050.548^{a}$ & 82 & 1049.397 & 2.620 & .000 \\
\hline Intercept & 3867589.069 & 1 & 3867589.069 & 9654.943 & .000 \\
\hline \multicolumn{6}{|l|}{ Single Factor Analysis } \\
\hline $\mathrm{W} / \mathrm{B}$ & 220.069 & 1 & 220.069 & .549 & .460 \\
\hline SAP content & 3812.275 & 2 & 1906.137 & 4.758 & $.010 * 1$ \\
\hline SAP type & 2914.238 & 1 & 2914.238 & 7.275 & $.008 * 1$ \\
\hline Binder type & 3139.936 & 1 & 3139.936 & 7.838 & $.006 * 1$ \\
\hline Curing Age & 963.080 & 2 & 481.540 & 1.202 & .304 \\
\hline \multicolumn{6}{|l|}{ Two Factor Analysis } \\
\hline $\mathrm{W} / \mathrm{B} * \mathrm{SAP}$ content & 607.826 & 2 & 303.913 & .759 & .471 \\
\hline W/B * SAP type & 1199.360 & 1 & 1199.360 & 2.994 & .086 \\
\hline $\mathrm{W} / \mathrm{B} *$ Curing Age & 5085.954 & 2 & 2542.977 & 6.348 & $.002 * 2$ \\
\hline SAP content $*$ SAP type & 402.668 & 2 & 201.334 & .503 & .606 \\
\hline SAP content $*$ Binder type & 392.120 & 2 & 196.060 & .489 & .614 \\
\hline SAP content $*$ Curing Age & 1779.739 & 4 & 444.935 & 1.111 & .355 \\
\hline SAP type $*$ Binder type & 68.479 & 1 & 68.479 & .171 & .680 \\
\hline SAP type $*$ Curing Age & 11191.428 & 2 & 5595.714 & 13.969 & $.000 * 2$ \\
\hline Binder type * Curing Age & 4629.895 & 2 & 2314.947 & 5.779 & $.004 * 2$ \\
\hline \multicolumn{6}{|l|}{ Three Factor Analysis } \\
\hline W/B $*$ SAP content $*$ SAP type & 3315.301 & 2 & 1657.650 & 4.138 & $.018 * 3$ \\
\hline W/B $*$ SAP content $*$ Curing Age & 1863.591 & 4 & 465.898 & 1.163 & .331 \\
\hline W/B $*$ SAP type $*$ Curing Age & 604.438 & 2 & 302.219 & .754 & .472 \\
\hline SAP content $*$ SAP type $*$ Binder type & 536.823 & 2 & 268.411 & 670 & .514 \\
\hline SAP content $*$ SAP type $*$ Curing Age & 1111.548 & 4 & 277.887 & .694 & .598 \\
\hline SAP content $*$ Binder type $*$ Curing Age & 4928.443 & 4 & 1232.111 & 3.076 & $.019 * 3$ \\
\hline SAP type $*$ Binder type $*$ Curing Age & 931.425 & 2 & 465.713 & 1.163 & .316 \\
\hline \multicolumn{6}{|l|}{ Four Factor Analysis } \\
\hline W/B $*$ SAP content $*$ SAP type $*$ Curing Age & 1432.025 & 4 & 358.006 & .894 & .470 \\
\hline SAP content $*$ SAP type $*$ Binder type $*$ Curing Age & 5918.920 & 3 & 1972.973 & 4.925 & $.003 * 4$ \\
\hline Error & 48069.747 & 120 & 400.581 & & \\
\hline Total & 4857480.375 & 203 & & & \\
\hline Corrected Total & 134120.295 & 202 & & & \\
\hline
\end{tabular}

a. $\quad$ R Squared $=.642$ (Adjusted R Squared $=.397)$

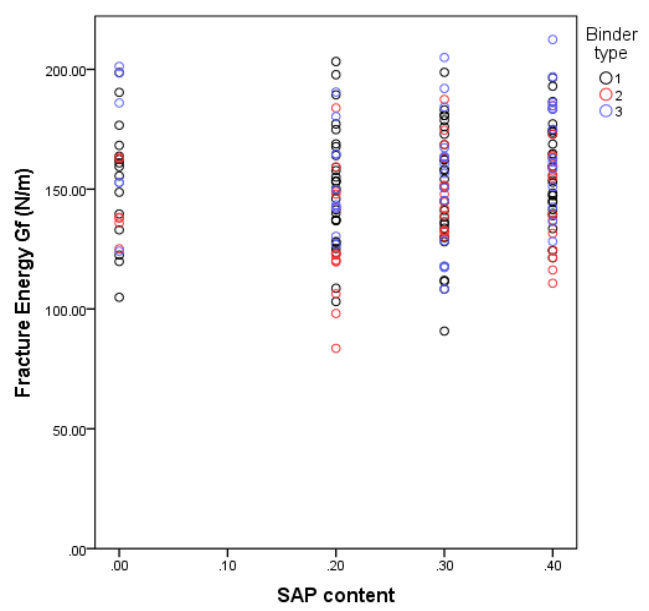

Figure 8: Gf vs. SAP contents as influenced by binder type

\section{Conclusion}

The findings of the experiment conducted in this research hereby concludes that AP addition within the limits of the contents used in this study ( 0.2 to $0.4 \%$ $\mathrm{b}_{\mathrm{wob}}$ ) in low W/B HPCs has no significant influence on the elastic and fracture properties of the concrete. Although the splitting force was slightly higher at lower SAP content, the ductility of the HPCs increased as the SAP contents increase, the most significant of the factors studied on the fracture properties is the binder type.

Authors hereby acknowledge the following: Mr. Guillaume Jeanson (Construction Product Manager) SNF Floerger - ZAC de Milieux, 42163 ANDREZIEUX Cedex - FRANCE; PPC Western Cape, South Africa, AshResources and Chryso, South Africa, the Southern African Concrete Society and the Tertiary Education Trust Fund (TETFund) Nigeria for the numerous 
assistance received, both financial and materials provision for the study.

\section{REFERENCES}

1. ACI THPC/TAC (1999), ACI defines high performance concrete, (the Technical Activities Committee Report (Chairman - H.G. Russell)). U.S.A: American Concrete Institute.

2. S. H. Kosmatka, B. Kerkhoff, \& W. C. Panarese, Chapter 17: High performance concrete, Design and control of concrete mixture: Engineering bulleting 001 (EB 001) (Fourteenth ed., pp. 299-314), Illinois, USA: Portland Cement Association, (2002).

3. A. M. Neville, Properties of concrete (Fifth ed.), England: Pearson Educational Limited, (2012).

4. International Federation for Structural Concrete (fib). Model code 2010 (final version), (fib Bulletins 65 \& 66), Lausanne: International Federation for Structural Concrete (fib) (2012).

5. X. Z. Hu, \& F. H. Wittmann, Experimental method to determine extension of fracture process zone. Journal of Mats. in Civil Engrg, 2, 15-23, (1990).

6. V. Mechtcherine, \& H. S. Müller, Fracture mechanical and fractological investigations on normal and high strength concrete, In A. M. Brand, V. C. Li \& I. H. Marshall (Eds.), Proceedings of the fifth international symposium on brittle matrix composites (Bigraf/Warshaw ed., 231-240), Cambridge, Woodhead Publishing Ltd. (1997).

7. F. H. Wittmann, P. E. Roelfstra, H. Mihashi, Y. Y. Huang, X. Zhang, \& K. Nomura, Influence of age at loading, water-cement ratio and rate of loading on fracture energy of concrete, Mats. \& Structs., Paris, 20, 103-110 (1987),

8. E. A. Hansen, M. Leive, J. Rodriguez, \& R. Cather, Mechanical properties of high strength concrete influence of test conditions, specimens and constituents. In I. Holand, \& E. J. Sellevold (Eds.), Proceedings of fourth international symposium on the utilization of high strength / high performance concrete (187-196). Paris, France (1996).

9. International Union of Testing and Research Laboratories for Materials and Structures (RILEM) AAC13.1 - Determination of the specific fracture energy and strain softening of AAC 1992, TC51-ALC, 78-MCA, RILEM technical recommendations for the testing and use of construction materials (156-158), London, E \& FN Spon (1994).

10. B. J. Olawuyi, \& W. P. Boshoff, Influence of SAP contents and curing age on air void distribution using $3 D$ volume analysis, Const. \& Bldg. Mats., 135, Elsevier Publishing, 580-589 (2017).

11. C. Schrofl, V. Mechtcherine, \& M. Gorges, Relation between the molecular structure and the efficiency of superabsorbent polymer (SAP) as concrete admixture to mitigate autogenous shrinkage, Cem. \& Conc. Res., 42, 865-873 (2012).

12. B. J. Olawuyi, \& W.P. Boshoff, Influence of particle size distribution on compressive strength and elastic modulus of high performance concrete, Proceedings of Advances in Cement and Concrete Technology in Africa (ACCTA) Conference, Johannesburg, South Africa, $28^{\text {th }}-30^{\text {th }}$ January, $825-834$ (2013).

13. British Standard Institution, Cement- Composition, Specifications and Conformity Criteria for common Cements, BS EN 197- 1, London, BSI (2000).

14. South African Bureau of Standards, SANS 50197 - 1 - Cement - Part 1: Composition, specifications and conformity criteria for common cements, Pretoria, (SABS) (2001).

15. P. C. Aītcin, High performance concrete, London \& New York, E \& FN Spon.

16. Beushausen, H., \& Dehn, F. High-performance concrete, In G. Owens (Ed.) Fulton's concrete technology (Ninth ed.), 297-304, Midrand, South Africa: Cement and Concrete Institute (2009).

17. M. S. Shetty, Concrete technology - theory and practice, New Dhelhi, India: S. Chand and Company Limited (2004).

18. F. Dehn, Constitutive concrete and durability models in the new fib model code 2010. Encontro Nacional BETÃO ESTRUTURAL (National Concrete Structural) - BE2012 FEUP, Portugal, (24 - 26 October) 1-12 (2012).

19. E. Brühwiler, \& F. H. Wittmann, The wedge splitting test, a new method for performing stable fracture mechanics test, Engrg. Fract. Mechs., 35(1/2/3), 117125 (1990).

20.Z, Zhao, S. H. Kwon, \& S. P. Shah, Effect of specimen size on fracture energy and softening curve of concrete: Part I. experiments and fracture energy, Cem. \& Conc. Res., 38 (2008).

21. B. Trunk, G. Schober, A. K. Helbing, \& F. H. Wittmann, Fracture mechanics parameters of autoclaved aerated concrete, Cem. \& Conc. Res., 29: 855-859 (1999),

22. B. J. Olawuyi, The mechanical behaviour of highperformance concrete with Superabsorbent Polymers (SAP), PhD Thesis, University of Stellenbosch, 221 pp. (2016).

23. H. Lam, \& R. D. Hooton, Effects of internal curing methods on restrained shrinkage and permeability, Portland Cement Association, Res. \& Devt. . $S / N .2620$, In: Proceeding $4^{\text {th }}$ International Seminar on Self-desiccation and its Importance in Concrete Technology, Persson, B., Bentz, D., \& Nilsson, L. O. (eds.), Lund University, Lund, Sweden, 201-228 (2005).

24. V. Mechtcherine, \& H. Reinhardt, (eds.), Application of super absorbent polymers (SAP) in concrete construction, RILEM State of the Art Reports, 2 (2012) 